\title{
MOLECULAR TYPING OF Giardia duodenalis ISOLATES FROM NONHUMAN PRIMATES HOUSED IN A BRAZILIAN ZOO
}

Érica Boarato DAVID(1), Mariella PATTI(2), Silvana Torossian CORADI(2), Teresa Cristina Goulart OLIVEIRA-SEQUEIRA(1), Paulo Eduardo Martins RIBOLLA(1) \& Semíramis GUIMARÃES(1)

\begin{abstract}
SUMMARY
Giardia infections in captive nonhuman primates (NHP) housed at a Brazilian zoo were investigated in order to address their zoonotic potential. Fresh fecal samples were collected from the floors of 22 enclosures where 47 primates of 18 different species were housed. The diagnosis of intestinal parasites after concentration by sedimentation and flotation methods revealed the following parasites and their frequencies: Giardia (18\%); Entamoeba spp. (18\%); Endolimax nana (4.5\%); Iodamoeba spp. (4.5\%); Oxyurid $(4.5 \%)$ and Strongylid (4.5\%). Genomic DNA extracted from all samples was processed by PCR methods in order to amplify fragments of $g d h$ and tpi genes of Giardia. Amplicons were obtained from samples of Ateles belzebuth, Alouatta caraya, Alouatta fusca and Alouatta seniculus. Clear sequences were only obtained for the isolates from Ateles belzebuth (BA1), Alouatta fusca (BA2) and Alouatta caraya (BA3). According to the phenetic analyses of these sequences, all were classified as assemblage A. For the tpi gene, all three isolates were grouped into sub-assemblage AII (BA1, BA2 and BA3) whereas for the gdh gene, only BA3 was subassemblage AII, and the BA1 and BA2 were sub-assemblage AI. Considering the zoonotic potential of the assemblage A, and that the animals of the present study show no clinical signs of infection, the data obtained here stresses that regular coproparasitological surveys are necessary to implement preventive measures and safeguard the health of the captive animals, of their caretakers and of people visiting the zoological gardens.
\end{abstract}

KEYWORDS: Giardia duodenalis; Molecular characterization; Nonhuman primates; Zoo; Zoonosis

\section{INTRODUCTION}

Today, in view of the increasing interest for biodiversity conservation, wildlife species have been subject to many investigations; however the search for knowledge goes beyond the behavioral and ecological aspects of these animals and includes research on their infectious diseases and their role in public health. For this purpose, studies have been carried out on the occurrence of enteric parasites in a range of wild mammals' species, many of them kept in zoological gardens, conservation parks or sanctuaries, where captivity may raise their exposure to conditions that facilitate the spread of these pathogens ${ }^{4,5,7,9,19,21}$. In this context, it is important to stress that a wide range of captive species may be important reservoirs for zoonotic parasites acting as potential sources of human and animal infections and environmental contamination.

The enteric protozoan Giardia duodenalis (syn. G. intestinalis, G. lamblia) is one of the most common pathogens of zoonotic importance that infect humans and domesticated animals, in addition to many other mammalian wildlife species, including free-living and captive animals ${ }^{1}$. Currently, genetic analyses have shown that human and animal isolates can be clustered into at least eight groups, referred to as genotypes A to $\mathrm{H}^{17,23}$, but only assemblages $\mathrm{A}$ and $\mathrm{B}$ are known to infect humans, as well as a variety of other mammals. Based on the data on the prevalence of giardiasis in different hosts and on existing knowledge of the genotypes of $G$. duodenalis, THOMPSON proposed the existence of transmission cycles that keep the infection among the mammals ${ }^{31}$. Even so, it has not been fully elucidated how these cycles interact and how often the transmission of zoonotic assemblages occurs.

Despite the interest of researchers, as yet, genotyping data from wildlife mammals' species are scarce. Lately, APPELBEE et al. highlighted that the infection of free-living and captive wildlife mammals by both host-adapted and zoonotic isolates of Giardia can provide insights into the host range and zoonotic potential of this parasite ${ }^{1}$. An overview of recent studies enables us to ascertain that almost all mammalian orders include free-living and captive species that can harbor Giardia isolates ${ }^{2,18,26}$. Among these groups, Giardia isolates have been obtained from nonhuman primates' species, however, until now, few studies have addressed the molecular characterization of these isolates and discussed their role in public health $3,5,15,20,22,32$.

(1) Departamento de Parasitologia, Instituto de Biociências, Universidade Estadual Paulista (UNESP), Botucatu, São Paulo, SP, Brazil

(2) Departamento de Ciências Biológicas e da Saúde, Universidade do Sagrado Coração (USC), Bauru, São Paulo, SP, Brazil.

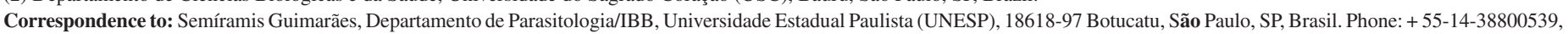
Fax: +55-14-38153744. E-mail: sgviana@ibb.unesp.br 
DAVID, E.B.; PATTI, M.; CORADI, S.T.; OLIVEIRA-SEQUEIRA, T.C.G.; RIBOLLA, P.E.M. \& GUIMARÃES, S. - Molecular typing of Giardia duodenalis isolates from nonhuman primates housed in a Brazilian zoo. Rev. Inst. Med. Trop. Sao Paulo, 56(1): 49-54, 2014.

Thus, we focused our attention here to verify the occurrence of the Giardia infection in nonhuman primates' fauna of the Bauru Municipal Zoological Garden (São Paulo State, Brazil).

\section{MATERIALS AND METHODS}

Study site and sampling: The Bauru Municipal Zoological Garden, located in the city of Bauru in São Paulo State, covers an area of 43.5ha and houses 880 animals of 210 species, comprising mammals, birds and reptiles. Before the start of the study, approval was obtained from the Research Ethics Committee at Sacred Heart University (105/10 CEP-USC) as well as by the zoo's administration. From September to November 2009, fecal samples from forty-seven primates of 18 species, belonging to three families of New World monkeys (Atelidae, Callitrichidae and Pitheciidae) and one of Old World (Cercopithecidae) were analyzed. The animals were either kept individually (five animals) or in monospecific groups of 2-7 individuals (42 animals) sharing the same enclosures (Table 1).

Due to the group housing, all the feces discharged by the animals in each pen were recovered from the floor and pooled in labeled plastic vials containing $2.5 \%$ potassium dichromate. For those animals kept alone in the enclosure, individual sampling was possible. Collection of stool was carried out in the morning, after the feeding of animals, on three alternate days.
The samples were assessed for helminthes and protozoans by conventional coprological techniques of spontaneous sedimentation and centrifuge-flotation with zinc sulfate, according to SLOSS et al. ${ }^{27}$. For Cryptosporidium diagnosis, a part of each stool sample was previously concentrated by centrifugation (500 xg, $10 \mathrm{~min}$ ) and the sediment obtained was used to prepare smears stained by a modified Ziehl-Neelsen technique ${ }^{13}$. An aliquot of this sediment was also stored at $-20{ }^{\circ} \mathrm{C}$ for subsequent DNA extraction.

DNA extraction: The genomic DNA was extracted using the QIAamp® Stool Mini Kit (Qiagen, Germany) following the manufacturer's instructions. Prior to extraction, the samples were subjected to three freeze/thaw cycles as follows: two cycles in liquid nitrogen for five min and at $70{ }^{\circ} \mathrm{C}$ for five min and concluding in liquid nitrogen for five min and thawed at $95{ }^{\circ} \mathrm{C}$ for five min. For molecular characterization of Giardia, DNA was extracted from all the samples regardless the coprological diagnosis.

PCR assays and sequencing: Molecular analysis was carried out by amplifying $g d h$ and tpi fragment genes. A nested PCR procedure was used to amplify a $530 \mathrm{bp}$ region of the tpi fragment using the primers AL3543 and AL3546 for the first step, and AL3544 and AL3545 for the second one ${ }^{29}$. For $g d h$, a semi-nested PCR was used to amplify a 432 bp fragment with the primers GDHeF and GDHiR in the primary reaction

Table 1

Intestinal parasites identified in nonhuman primates at Bauru zoo and G. duodenalis PCR analysis

\begin{tabular}{|c|c|c|c|c|}
\hline Primate specie & Common name & $\begin{array}{c}\text { No. of animals (no. enclo- } \\
\text { sures) }\end{array}$ & Coprological analysis & Giardia PCR \\
\hline Alouatta caraya & Black howler monkey & $4(1)$ & Giardia, Entamoeba spp & + \\
\hline Alouatta fusca & Brown howler monkey & $3(1)$ & Giardia & + \\
\hline Alouatta seniculus & Red howler monkey & $4(2)$ & $\begin{array}{l}\text { Giardia, Entamoeba spp, } \\
\text { Endolimax nana }\end{array}$ & + \\
\hline Ateles belzebuth & White-fronted spider monkey & $2(1)$ & Giardia, Iodamoeba bütschilii & + \\
\hline Ateles fusciceps & Brown-headed spider monkey & $2(1)$ & - & - \\
\hline Ateles paniscus & Red-faced spider monkey & $5(1)$ & Oxyurid eggs & - \\
\hline Callicebus nigrifrons & Black-fronted titi monkey & $2(1)$ & - & - \\
\hline Callithrix argentata & Silvery marmoset & $2(1)$ & - & - \\
\hline Callithrix geoffroyi & Geoffroy's tufted-ear marmoset & 1 & - & - \\
\hline Lagothrix lagotricha & Woolly monkey & $5(3)$ & - & - \\
\hline Leontopithecus chrysomelas & Golden-headed lion tamarin & $7(2)$ & - & - \\
\hline Leontopithecus rosalia & Golden lion tamarin & $2(1)$ & Strongyle-type eggs & - \\
\hline Mandrillus sphinx & Mandrill & $2(1)$ & Entamoeba spp & - \\
\hline Papio hamadryas & Hamadryas baboon & 1 & - & - \\
\hline Papio papio & Guinea baboon & $2(1)$ & - & - \\
\hline Saguinus bicolor & Brazilian bare-faced tamarim & 1 & - & - \\
\hline Saguinus fuscicollis & Brown-headed tamarin & 1 & - & - \\
\hline Saguinus melanoleucus & White saddleback tamarin & 1 & Entamoeba spp & - \\
\hline
\end{tabular}

- negative samples 


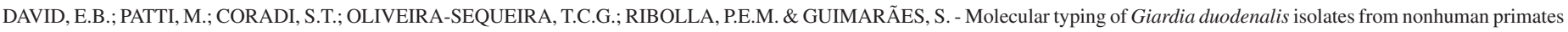
housed in a Brazilian zoo. Rev. Inst. Med. Trop. Sao Paulo, 56(1): 49-54, 2014.

and GDHiF and GDHiR in the secondary ${ }^{25}$ one. In all PCR reactions, positive (DNA from axenic Giardia culture) and negative controls were included. The amplified products were submitted to $1.5 \%$ agarose gel electrophoresis, stained with ethidium bromide.

Bands of the predicted sizes were excised from agarose gel, then, DNA was purified using the Ultrafree ${ }^{\circledR}$ DA kit (Millipore Corp., USA) and sequenced in both directions in Macrogen Inc. (Seoul, Korea). The nucleotide sequences obtained were manually corrected and multiple alignments for each locus were performed using CLUSTAL $\mathrm{X}$ version $1.8^{30}$ and queried against known sequences of GenBank database using BLAST. The phenetic analyses were performed with the MEGA software (http://www.mega-software.net) and the sequences obtained in the present study were deposited in the GenBank data base under accession numbers JN172997-JN172999 for $g d h$ sequences, and JN410841-JN410843 for tpi sequences.

The DNA sequences were translated into amino acids using the online software Emboss gui - European Molecular Biology Open Software Suite (http://bips.u-strasbg.fr/EMBOSS/).

\section{RESULTS AND DISCUSSION}

The microscopic examination of stool samples revealed that enteric parasites pathogenic and/or non pathogenic were detected in samples from $36 \%(8 / 22)$ of the enclosures. Among the 18 species of primates, intestinal parasites were found in feces from animals belonging to the genera Ateles, Alouatta, Leontopithecus, Mandrillus and Saguinus (Table 1). Giardia cysts were found in the feces collected in four enclosures (18\%) where animals of the following species were kept: Ateles belzebuth, Alouatta seniculus, Alouatta caraya and Alouatta fusca (Table 1). Other intestinal protozoa were identified and their frequencies were as following: Entamoeba spp (18\%), Iodamoeba butschlii (4.5\%) and Endolimax nana (4.5\%). No Cryptosporidium oocysts were found on fecal smears of all assessed samples. Parasitism by helminthes was detected in animals from two enclosures, whose fecal samples were positive for strongylid and oxyurid nematodes eggs (Table 1).

The occurrence of both protozoa and helminthes have been reported in captive nonhuman primates of different regions ${ }^{5,7,9,16,19,24}$, with the predominance of the former ${ }^{7,19,20}$. According to some authors, the most frequent occurrence of protozoa infections can be explained by factors such as the short prepatent period, being immediately infective when excreted and the low infective dose required ${ }^{19}$ for infection. Besides, the restricted and collective environments conditions where the animals are kept facilitate protozoan transmission, because these organisms can be acquired through direct contact, which may be favored by primates' highly social nature. In the present study, besides the occurrence of the protozoa Giardia and species of amoebae, the detection of oxyurid eggs reinforces these aspects, since unlike most other nematodes, this helminth is already able to infect the host when passed in feces.

Likewise as previously reported in the literature ${ }^{5,19}$, herein, Giardia and Entamoeba spp. were the most frequent parasites diagnosed in NHP. Nevertheless, the clinical relevance of these infections is difficult to ascertain, especially regarding to Entamoeba, because several species are considered non-pathogenic ${ }^{5}$. So, the known species considered pathogenic for NHP include $E$. histolytica and its virulent variant $E$. nuttalli ${ }^{5}$. However, through direct microscopic identification of the parasite, it is impossible to distinguish between E. histolytica and the non-pathogenic species E. dispar and E. moshkovskii, once these amoebae are morphologically indistinguishable. It is important to emphasize that, although Giardia and Entamoeba spp. are commonly found in stools of wild and captive NHP and can be a significant cause of diarrhea, in the present survey, all fecal samples had a normal consistency and animals showed no symptoms of infection, even when both protozoan were detected in animals kept in the same pen (Table 1).

Given that Cryptosporidium is an important pathogenic protozoa that has been detected in a range of captive mammals' species ${ }^{7,11,15,19,21,24}$, it was expected that this parasite could be detected in the animals of the present study. It is noteworthy that the occurrence of Cryptosporidium infection is still underestimated, since its diagnosis depends on the identification of oocysts in fecal smears stained, being a more laborious method that is generally not included in many surveys. This was not the point in our study since smears were prepared and examined, but a likely reason for negative results of Cryptosporidium could be the analysis of pooled stool samples, despite efforts to concentrate the material.

Although the increasing interest to gain insight into the role of nonhuman primates as hosts of Giardia, molecular characterization of isolates from New World species is still limited, especially in Brazil, which is the world's richest country in primate species diversity.

Herein, the four Giardia-positive samples produced PCR products of the expected size in the $g d h$ and tpi genes, but no amplicon was obtained from the eighteen Giardia cyst-negative samples assessed. Clear sequences of amplicons were only obtained for the isolates from Ateles belzebuth (BA1), Alouatta fusca (BA2) and Alouatta caraya (BA3) (Tables 1 and 2). A comparison of these sequences with the homologous $g d h$ and $t p i$ deposited in GenBank showed that all three isolates were assigned to assemblage A (Table 2; Fig. 1). Taking as reference the comparative evaluation of $G$. duodenalis sequence data carried out by WIELINGA $\&$ THOMPSON, the alignment between these three sequences and other ones from humans and nonhuman primates revealed that in tpi locus, the isolates BA1 (JN410841), BA2 (JN410842), and BA3 (JN410843) were subtype AII, whereas in the $g d h$ locus, only the isolate BA3 (JN172999) was classified as AII and the isolates BA1 (JN172997) and BA2 (JN172998) corresponded to sub-assemblage AI (Fig. 1; Table 2).

Interestingly, in regards to the analysis of polymorphisms in the nucleotide sequences (SNPs) obtained for the gdh gene, the BA2 (JN172998) isolate did show 100\% homology with reference strains for sub-assemblage AI while the isolates BA1 (JN172997) and BA2 (JN172998) revealed at least one SNP (Table 2). Thus, the isolate BA1 showed one SNP at position 666, and the BA3 showed the same SNP at position 666 and a novel one at position 621(Table 2). Among the tpi sequences, the isolates BA2 (JN410842) and BA3 (JN410843) did show $100 \%$ homology with reference strains for sub-assemblage AII whereas the isolate BA1 (JN410841) reveled a novel SNP at position 107 (Table 2). In all sequences retrieved, nucleotide substitutions were characterized as transitions and the SPNs were synonymous, resulting in no change in the amino acids encoded. So, only in the tpi sequence of isolate BA1 (JN410841), a non-synonymous SNP in position 634 determined a change in the deduced amino acid sequence leading to a replacement of a serine by a phenylalanine. 


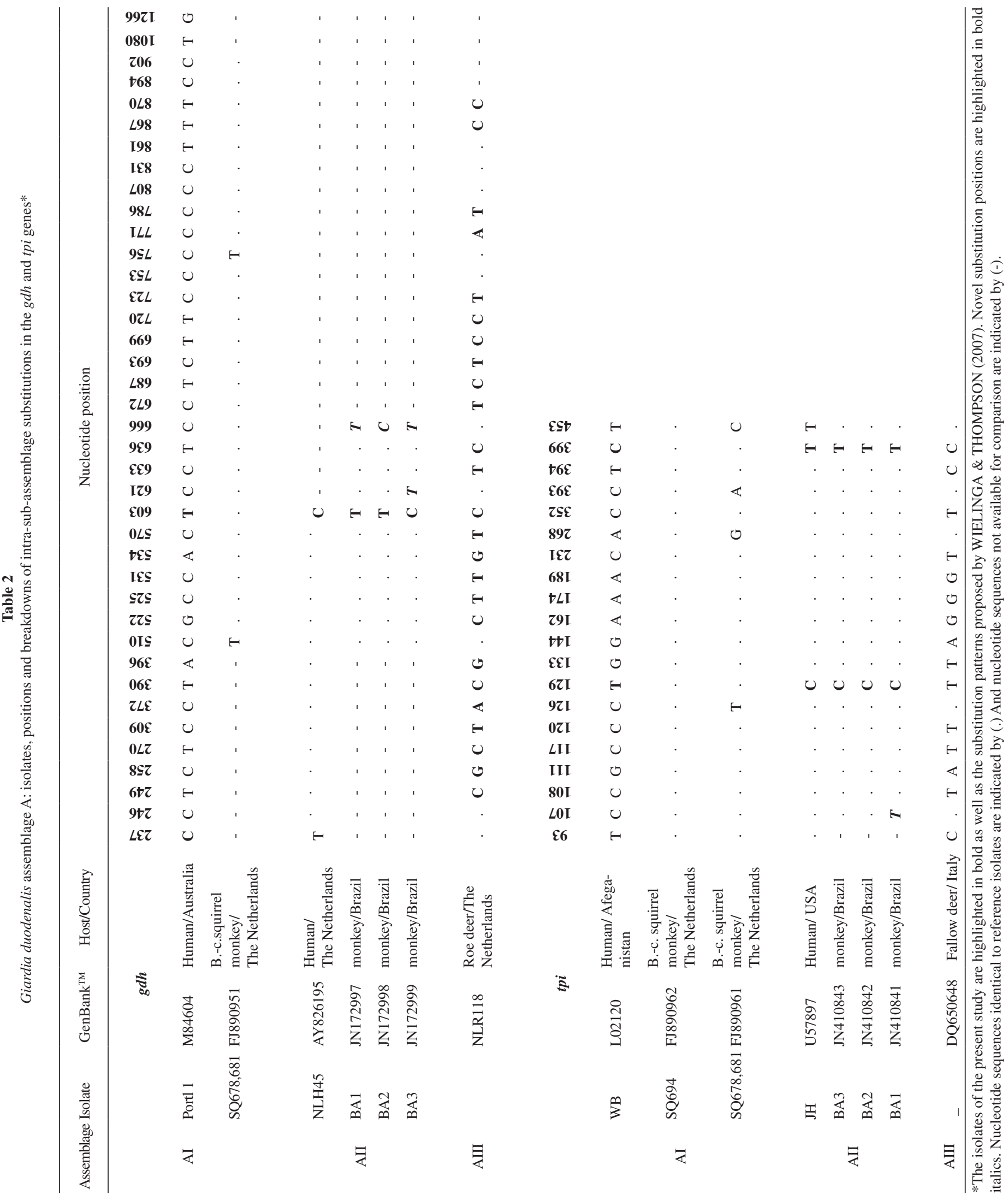




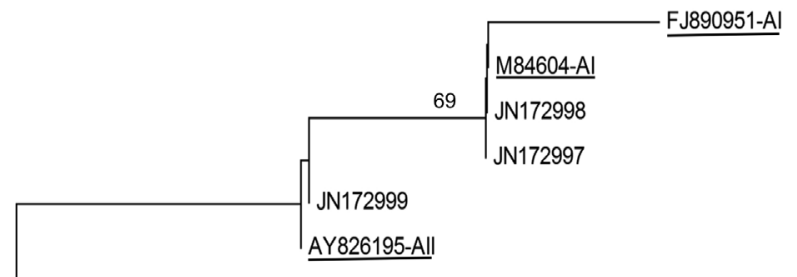

DQ100288-AIII

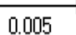

gdh

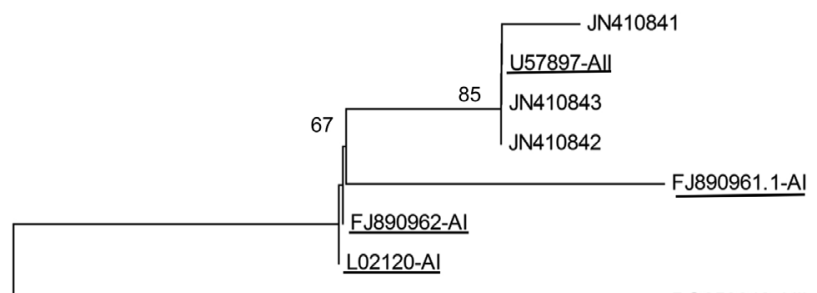

DQ650648-AIII

Fig. 1 - Dendrograms of Giardia duodenalis based on nucleotide sequences of $g d h$ and tpi genes. Trees were constructed using the neighbor-joining method implemented by the computer program Mega 4.1. Bootstrap values were calculated by the analysis of 1000 simulations (only bootstrap values $>50 \%$ are shown). The reference sequences for both genes are underlined.

In the present study, the finding of infection within assemblage A, confirms previous reports that have detected the same genotype in either the $g d h$ or the tpi locus ${ }^{20,22}$ as well as in $\beta$-giardin ${ }^{20,32}$ and SSUrRNA ${ }^{12}$ genes. Additionally, in these studies, assemblage A subtypes were identified as either AI or AII.

Recently, both assemblages A and B were found in New World monkeys ${ }^{14,20,28,32}$, including species that live in South American forests ${ }^{28,32}$. In Brazil, the occurrence of genotype A in NHP was first reported by VOLOTÃO and colleagues, who detected only isolates belonging to the AI assemblage in samples from southern brown howler monkeys (Alouatta clamitans) $^{32}$. In contrast, SOARES et al. recently identified assemblage B in all the samples from 20 howler monkeys Alouatta fusca housed in a wild animal center ${ }^{27}$.

With respect to the separation of isolates into sub-assemblages, herein, the inconsistency observed among the loci assessed is not an unusual situation. According to authors BONHOMME et al., inconsistent results are sometimes generated when different loci are targeted, especially regarding the subtypes. Thus, in spite of the possibility of assemblage swapping, explaining different assemblages or sub-assemblages in different loci in the same isolate has not been an easy task.

Despite the finding of two different sub-assemblages in the same isolate, as we can see, the infection of captive nonhuman primates within assemblage A has an epidemiological relevance, since this genetic group is zoonotic and the most common non-host specific assemblage in animals ${ }^{10}$.

Concerning subtypes of this assemblage, AI and AII are the two most frequently involved in the infections, even though they appear to differ in host preference, since there is evidence that humans are more commonly infected with AII whereas animals are more commonly infected with $\mathrm{AI}^{10}$. However, both subgroups have been detected in humans and animals.

Finally, despite the low number of tested isolates, the results presented herein outline some pertinent aspects about the occurrence of G. duodenalis assemblages in captive nonhuman primates' species and also provide insights for future elucidation of Giardia epidemiology in endemic areas. All things considered, this kind of investigation highlights the importance of coproparasitological surveys as part of practice in zoos in order to implement preventive measures and safeguard the health of captive animals and people near them (animal keepers and visitors). In this context, it is appropriate to take into account that the transmission of pathogens between humans and nonhuman species has to be considered in either direction, so that recognizing the links between human, animal and ecosystem health can provide an effective approach to understanding the transmission of pathogens among these hosts ${ }^{8}$.

\section{RESUMO}

\section{Genotipagem de isolados de Giardia duodenalis de primatas não humanos mantidos em zoológico do Brasil}

A pesquisa de infecções por Giardia e a caracterização genotípica deste protozoário foi realizada em primatas não humanos (PNH) mantidos em Zoológico a fim de avaliar o seu potencial zoonótico. As amostras dos animais consistiram de fezes colhidas do piso de 22 baias onde eram mantidos 47 primatas de 18 diferentes espécies. Exames coproparasitológicos foram realizados pelos métodos de concentração por sedimentação e centrífugo-flutuação e revelaram a presença dos seguintes parasitas e suas respectivas frequências: Giardia $(18 \%)$; Entamoeba spp. (18\%); Endolimax nana (4.5\%); Iodamoeba spp. (4.5\%); oxiurídeos (4.5\%) e estrongilídeos (4.5\%). O DNA extraído de todas as amostras fecais foi submetido à técnica de PCR para a amplificação dos genes gdh e tpi de Giardia, porém, só foram obtidos amplicons das quatro amostras positivas provenientes de Ateles belzebuth, Alouatta caraya, Alouatta fusca and Alouatta seniculus. O seqüenciamento dos fragmentos amplificados foi possível apenas para as amostras oriundas de Ateles belzebuth (BA1), Alouatta fusca (BA2) e Alouatta caraya (BA3), cuja análise fenética de ambos os genes revelou pertencerem ao genótipo A. As análises das sequências de tpi revelaram que todas as amostras pertencem ao subgenótipo AII. No que se refere ao gene $g d h$ as análises revelaram uma amostra pertencente ao subgenótipo AII (BA3) e duas ao subgenótipo A1 (BA1 e BA2). Considerando o potencial zoonótico do genótipo A e o fato de que os animais não apresentavam sintomas de infecção, os dados do presente trabalho salientam a importância de se realizar, periodicamente, exames coproparasitológicos dos animais de zoológico, para implementação de medidas preventivas para resguardar a saúde dos animais em cativeiro, a de seus tratadores e dos visitantes de parques zoológicos.

\section{ACKNOWLEDGEMENTS}

The authors wish to thank the administrative members of the Bauru Zoological Garden for giving permission to use the animals' feces and, to all animal keepers for providing assistance during fecal samples collection. 


\section{CONFLICT OF INTEREST}

The authors declare that there is no conflict of interest.

\section{REFERENCES}

1. Appelbee AJ, Thompson RC, Olson ME. Giardia and Cryptosporidium in mammalian wildlife: current status and future needs. Trends Parasitol. 2005;21:370-6.

2. Ash A, Lymbery A, Lemon J, Vitali S, Thompson RC. Molecular epidemiology of Giardia duodenalis in an endangered carnivore. The African painted dog. Vet Parasitol. 2010;174:206-12.

3. Beck R, Sprong H, Bata I, Lucinger S, Pozio E, Cacciò SM. Prevalence and molecular typing of Giardia spp. in captive mammals at the zoo of Zagreb, Croatia. Vet Parasitol. 2011;175:40-6.

4. Beck R, Sprong H, Lucinger S, Pozio E, Cacciò SM. A large survey of Croatian wild mammals for Giardia duodenalis reveals a low prevalence and limited zoonotic potential. Vector Borne Zoonotic Dis. 2011;11:1049-55.

5. Berrilli F, Prisco C, Friedrich KG, Di Cerbo P, Di Cave D, De Liberato C. Giardia duodenalis assemblages and Entamoeba species infecting non-human primates in an Italian zoological garden: zoonotic potential and management traits. Parasit Vectors. 2011;4:199.

6. Bonhomme J, Le Goff L, Lemée V, Gargala G, Ballet JJ, Favennec L. Limitations of $t p i$ and $b g$ genes sub-genotyping for characterization of human Giardia duodenalis isolates. Parasitol Int. 2011:60:327-30.

7. Cordón PG, Prados AH, Romero D, Moreno MS, Pontes A, Osuna A, et al. Intestinal parasitism in the animals of the zoological garden "Peña Escrita" (Almuñecar, Spain). Vet Parasitol. 2008;156:302-9.

8. Epstein JH, Price JT. The significant but understudied impact of pathogen transmission from humans to animals. Mt Sinai J Med. 2009;76:448-55.

9. Fagiolini M, Lia RP, Laricchiuta P, Cavicchio P, Mannella R, Cafarchia C, et al. Gastrointestinal parasites in mammals of two Italian zoological gardens. J Zoo Wildl Med. 2010;41:662-70.

10. Feng Y, Xiao L. Zoonotic potencial and molecular epidemiology of Giardia species and giardiasis. Clin Microbiol Rev. 2011;24:110-40.

11. Geurden T, Goossens E, Levecke B, Vercammen F, Vercruysse J, Claerebout E. Occurrence and molecular characterization of Cryptosporidium and Giardia in captive wild ruminants in Belgium. J Zoo Wildl Med. 2009;40:126-30.

12. Graczyk TK, Bosco-Nizeyi J, Ssebide B, Thompson RC, Read C, Cranfield MR. Anthropozoonotic Giardia duodenalis genotype (assemblage) A infections in habitats of free-ranging human-habituated gorillas, Uganda. J Parasitol. 2002;88:905-9.

13. Henriksen A, Pohlenz JFL. Staining of Cryptosporidia by a modified Ziehl-Neelsen technique. Acta Vet Scand. 1981;22:594-6.

14. Itagaki T, Kinoshita S, Aoki M, Itoh N, Saeki H, Sato N, et al. Genotyping of Giardia intestinalis from domestic and wild animals in Japan using glutamate dehydrogenase gene sequencing. Vet Parasitol. 2005;133:283-7.

15. Kowalewski MM, Salzer JS, Deutsch JC, Raño M, Kuhlenschmidt MS, Gillespie TR. Black and gold howler monkeys (Alouatta caraya) as sentinels of ecosystem health: patterns of zoonotic protozoa infection relative to degree of human-primate contact. Am J Primatol. 2011;73:75-83

16. Labes EM, Hegglin D, Grimm F, Nurcahyo W, Harrison ME, Bastian ML, et al. Intestinal parasites of endangered orangutans (Pongo pygmaeus) in Central and East Kalimantan, Borneo, Indonesia. Parasitology. 2010;137:123-35.
17. Lasek-Nesselquist E, Welch DM, Sogin ML. The identification of a new Giardia duodenalis assemblage in marine vertebrates and a preliminary analysis of $G$ duodenalis population biology in marine systems. Int J Parasitol. 2010;40:1063-74

18. Lebbad M, Mattsson JG, Christensson B, Ljungström B, Backhans A, Andersson JO, et al. From mouse to moose: multilocus genotyping of Giardia isolates from various animal species. Vet Parasitol. 2010;168:231-9.

19. Levecke B, Dorny P, Geurden T, Vercammen F, Vercruysse J. Gastrointestinal protozoa in non-human primates of four zoological gardens in Belgium. Vet Parasitol. 2007; 148:236-46.

20. Levecke B, Geldhof P, Claerebout E, Dorny P, Vercammen F, Cacciò SM, et al. Molecula characterisation of Giardia duodenalis in captive non-human primates reveals mixed assemblage A and B infections and novel polymorphisms. Int J Parasitol. 2009;39:1595-601

21. Lim YA, Ngui R, Shukri J, Rohela M, Mat Naim HR. Intestinal parasites in various animals at a zoo in Malaysia. Vet Parasitol. 2008;157:154-9.

22. Martínez-Díaz RA, Sansano-Maestre J, Martínez-Herrero MD, Ponce-Gordo F, Gómez-Muñoz MT. Occurrence and genetic characterization of Giardia duodenalis from captive nonhuman primates by multi-locus sequence analysis. Parasitol Res. 2011;109:539-44.

23. Monis PT, Andrews RH, Mayrhofer G, Ey PL. Genetic diversity within the morphologica species Giardia intestinalis and its relationship to host origin. Infect Genet Evol. 2003;3:29-38

24. Muriuki SM, Murugu RK, Munene E, Karere GM, Chai DC. Some gastro-intestina parasites of zoonotic (public health) importance commonly observed in old world non-human primates in Kenya. Acta Trop. 1998;71:73-82.

25. Read CM, Monis PT, Thompson RC. Discrimination of all genotypes of Giardia duodenalis at the glutamate dehydrogenase locus using PCR-RFLP. Infect Genet Evol. 2004;4:125-30

26. Robertson LJ, Forberg T, Hermansen L, Hamnes IS, Gjerde B. Giardia duodenalis cysts isolated from wild moose and reindeer in Norway: genetic characterization by PCR RFLP and sequence analysis at two genes. J Wildl Dis. 2007;43:576-85

27. Sloss, MW, Zajac AN, Kemp, RL. Parasitologia clínica veterinária. 6 ed. São Paulo: Manole; 1999

28. Soares RM, de Souza SL, Silveira LH, Funada MR, Richtzenhain LJ, Gennari SM. Genotyping of potentially zoonotic Giardia duodenalis from exotic and wild animals kept in captivity in Brazil. Vet Parasitol. 2011;180:344-8.

29. Sulaiman IM, Fayer R, Bern C, Gilman RH, Trout JM, Schantz PM, et al. Triosephosphate isomerase gene characterization and potential zoonotic transmission of Giardia duodenalis. Emerg Infect Dis. 2003;9:1444-52.

30. Thompson JD, Gibson TJ, Plewniak F, Jeanmougin F, Higgins DG. The Clustal_X windows interface: flexible strategies for multiple sequence alignment aided by quality analysis tools. Nucleic Acids Res. 1997;25:4876-82.

31. Thompson, RC. The zoonotic significance and molecular epidemiology of Giardia and giardiasis. Vet Parasitol. 2004;126:15-35

32. Volotão AC, Souza Júnior JC, Grassini C, Peralta JM, Fernandes O. Genotyping of Giardia duodenalis from Southern Brown Howler Monkeys (Alouatta clamitans) from Brazil. Vet Parasitol. 2008;158:133-7.

33. Wielinga CM, Thompson, RCA. Comparative evaluation of Giardia duodenalis sequence data. Parasitology. 2007;134:1795-821.

Received: 25 July 2012

Accepted: 5 June 2013 